Malaysian Journal of Social Sciences and Humanities (MJSSH)

Volume 4, Issue 8, December 2019

e-ISSN : 2504-8562

Journal home page:

www.msocialsciences.com

\title{
Pengaruh Pengurusan Program Terhadap Interaksi Sosial di dalam Program Pendidikan Luar Pusat Kokurikulum Negeri Sabah
}

\author{
Suhairullah Bin Omar Ramih'1, Ambrews Andau' ${ }^{1}$, Roslee Bin Talip ${ }^{2}$, Muhamad Suhaimi Bin Taat ${ }^{2}$ \\ 1 Pusat Kokurikulum Negeri Sabah, Jabatan Pendidikan Negeri Sabah \\ 2Fakulti Psikologi dan Pendidikan, Universiti Malaysia Sabah (UMS)
}

Correspondence: Suhairullah Bin Omar Ramih (pkkspunya@gmail.com)

\begin{abstract}
Abstrak
Kajian ini melihat kepada pengaruh pengurusan program terhadap interaksi sosial dalam program pendidikan luar di Pusat Kokurikulum Sabah. Kajian kuantitatif ini menggunakan instrumen soal selidik. Seramai 113 responden telah terlibat dari kawasan pantai barat Sabah. Dapatan kajian menerangkan skor min bagi tahap pengurusan program dan interaksi sosial adalah pada tahap tinggi. Manakala hasil korelasi menunjukkan terdapat hubungan positif yang signifikan namun bersifat sederhana $(\mathrm{r}=0.469, \mathrm{k}<0.05)$. Lanjutan daripada korelasi yang terhasil, ujian regresi seterusnya menunjukkan bahawa nilai $\mathrm{R}$ square adalah 0.220 menjelaskan sebanyak $22 \%$ varians dalam pembolehubah pengurusan program mampu menjelaskan mengenai pembolehubah bersandar iaitu interaksi sosial $\left(\mathrm{F}_{1,111}=31.360, \mathrm{k}<0.05\right)$. Justeru implikasi daripada kajian ini membawa kepada dua perkara iaitu pada bahagian teori yang menyokong penggunaan sistem sokongan (scaffolding) dan pengurusan saintifik serta bahagian kedua implikasi dari segi kajian.
\end{abstract}

Kata kunci: pengurusan program pendidikan luar, interaksi sosial, Pusat Kokurikulum Sabah

\section{The Influence of Program Management on Social Interaction in the Sabah State Curriculum Outdoor Education Program}

\begin{abstract}
This study looks at the impact on program management on social interaction in outdoor education programs at Sabah Co-Curriculum Center. This quantitative study uses questionnaire instruments. A total of 113 respondents were involved in the west coast of Sabah. The findings show that mean scores for program management and social interaction levels are high. While the correlation results showed a significant but modest positive relationship $(\mathrm{r}=0.469, \mathrm{k}<0.05)$. Further on the resulting correlation, the regression test further showed that the $\mathrm{R}$ square value of 0.220 explained $22 \%$ of variance in program management variables capable of explaining the dependent variables, social interaction ( $\mathrm{F}$ $1,111=31.360, \mathrm{k}<0.05)$. Therefore, the implications of this study lead to two areas, namely, the theory section that supports the use of scaffolding and scientific management and the second part of the research implications.
\end{abstract}

Keywords: program management, outdoor education, social interaction, Sabah Co-Curriculum Center 


\section{Pengenalan}

Pendidikan luar merupakan suatu proses pembelajaran yang membawa pelajar terlibat secara langsung dengan dunia sebenar. Ia menjadikan pelajar merasai proses pembelajaran sebenar sebagai "makmal hidup" dan ia mampu mempromosikan pembelajaran yang melibatkan interaksi sosial peserta dan secara menyeluruh bagi menambah pengalaman mereka secara langsung dalam melakukan sesuatu perkara. Isu yang terhasil diperingkat sekolah rendah dan menengah masa kini adalah kebarangkalian penghasilan pelajar yang mempunyai penekanan tinggi dan kemahiran dari segi kognitif atau intelektual sahaja (iq-intelectual quotient). Hal ini mungkin disebabkan potensi pelajar disekolah mungkin terhalang atas faktor-faktor tertentu seperti persekitarannya sendiri (Rorlinda et.al, 2016). Namun di dalam pendidikan luar, di sini dapat dilihat keseimbangan dari segi kognitif, afektif dan psikomotor yang dibangunkan oleh potensi pengurusan program pendidikan luar itu sendiri. Pendidikan luar memberikan pengetahuan secara terus kepada peserta-peserta yang mengikuti program pendidikan luar. Keadaan ini memberikan perspektif baharu kepada peserta untuk berfikir dan merasai (peningkatan dan pembelajaran kecerdasan emosi) bersama-sama dengan peserta lain bagaimana seharusnya bertindak dalam sesuatu keadaan yang melibatkan risiko tinggi berdasarkan bantuan dan panduan jurulatih pendidikan luar Pusat Kokurikulum.

\section{Pernyataan Masalah}

Pihak pengurusan Pusat Kokurikulum merupakan perancang sesebuah program pendidikan luar dan menyediakan prasarana yang berkaitan bagi menjayakan sesebuah program tersebut,kekurangan prasarana mampu mengurangkan keefektifan sesebuah program pendidikan luar (Taff, Aziz dan Zakaria, 2011). Peserta yang hadir dari segenap pelusuk negeri atapun sekurang-kurangnya berlainan sekolah akan mendiami dan berkongsi (berkongsi khemah) kawasan perkhemahan yang telah dikenalpasti melalui pengurusan program yang telah dilaksanakan. Terdapat masalah keselesaan atau pelbagai faktor seperti tempat tinggal yang mungkin mempengaruhi perubahan sikap peserta terhadap alam sekitar beserta persepsi mereka (Omar Firdaus, 2016). Keadaan ini mampu memberikan kesan negatif dan ketegangan terhadap interaksi dalam program Pendidikan Luar. Pusat Kokurikulum Sabah kini mempunyai pelbagai prasarana bagi menampung kegiatan pendidikan luar ini, namun bagi melihat kepada prasarana dan pengurusannya, adalah menjadi persoalan adakah kemudahan atau prasarana yang ada akan mampu memberi impak dan persepsi yang baik terhadap tiga dimensi interaksi sosial di dalam pendidikan luar di Pusat Kokurikulum yang ingin dilihat oleh pengkaji.

Pengurusan program yang dirancang oleh pihak urusetia adalah bermatlamat bagi mendedahkan dan menarik minat pelajar mengenai pendidikan luar berdasarkan acuan tahap pembelajaran yang dibenarkan oleh Kementerian Pendidikan Malaysia. Bagi Sesetengah program pendidikan luar di luar negara seperti Canada (Bowdridge, 2010), Australia (Gray dan Martin, 2012), dan New Zealand (Irwin dan Straker, 2015) penyelarasan pengurusan program pendidikan luar adalah berada di peringkat nasional dan diangkat menjadi salah satu kurikulum di sekolah. Namun di Malaysia, sungguhpun tetapan (setting) kurikulum pendidikan luar telah diangkat ke peringkat nasional, ia tidak diletakkan di bawah tanggungjawab sekolah untuk melaksanakannya, tetapi diletakkan kepada Pusat Kokurikulum setiap negeri sebagai badan khas pelaksana pengurusan program pendidikan luar bagi kementerian pendidikan. Pelajar-pelajar akan dipilih oleh sekolah untuk dihantar masuk bersaing di dalam programprogram pendidikan luar di Pusat Kokurikulum pada peringkat negeri sehingga ke peringkat kebangsaan. Justeru, kecekapan pengurusan program Pusat Kokurikulum itu sendiri sebenarnya mungkin mampu memberikan persepsi secara tidak langsung kepada organisasi yang melaksanakannnya.

Spiers (2012) menyatakan pengurusan rekreasi atau program mempunyai dua bahagian iaitu secara langsung dan tak langsung. Pengurusan program di Pusat Kokurikulum mempunyai dua sisi bahagian yang berbeza, salah satu diantaranya adalah pengurusan program langsung yang akan melibatkan terus peserta berhadapan dengan pihak pengurusan seperti urusetia pendaftaran, pengurusan perkhemahan, makanan aktiviti dan sebagainya. Justeru, pada sisi ini dinilai sama ada ia mampu memberi sebarang 
persepsi kepada peserta (pelajar) mengenai keberkesanan program pendidikan luar dari segi kognitif, afektif dan psikomotor yang dikendalikan di Pusat kokurikulum.

\section{Definisi Istilah}

\section{Pengurusan program Pendidikan Luar}

Pengurusan adalah satu perkara yang melibatkan perlakuan sesuatu perkara secara sistematik melalui langkah-langkah yang tersusun. Mohd Salleh (2005) memberi pendapat bahawa pengurusan adalah suatu proses mengendalikan sumber-sumber fizikal yang sedia ada dengan merancang, mengorganisasi, mengawal dan memimpin terlebih dahulu bagi memacu kejayaan dalam sesuatu perkara. Setiap kejayaan dalam pengurusan merupakan pencapaian bagi pengurus, dan juga sebaliknya sekiranya berlaku kegagalan. Manakala Jones dan George (2015) didalam pengurusan kontemporari menyatakan pengurusan melibatkan 4 perkara asas iaitu merancang (Planning), Memimpin (Leading), Mengawal (Controlling), dan Menyusun kerja (Organising). Dengan maksud lain, pengurusan sebenarnya merancang, mengorganisasi, mengetuai dan mengawal sumber-sumber yang ada untuk mencapai sasaran atau matlamat organisasi dengan cekap dan berkesan.

Sementara itu bagi program pula, program latihan adalah salah satu cara atau prosedur yang digunakan oleh jurulatih sebagai panduan bagi melakukan sesuatu aktiviti seperti melatih individu atau atlet dalam tempoh tertentu (Anuar Din, Salleh Rashid, dan Mohd Isha Awang, 2015). Di Pusat Kokurikulum, pengurusan program yang dilaksanakan tidaklah menjurus kepada penghasilan atlet, namun ia masih menggunakan prosedur yang sama iaitu melaksanakan pengurusan program dalam aktiviti pendidikan luar agar ia menjadi lebih efisyen dan sistematik serta mampu memberi impak yang lebih baik kepada peserta. Selain itu, pengurusan program di Pusat kokurikulum dapat dibahagikan kepada dua bahagian iaitu langsung dan tak langsung. Bahagian pengurusan program langsung (direct management) akan melibatkan terus peserta berhadapan dengan pihak pengurusan seperti urusetia pendaftaran, pengurusan perkhemahan, makanan, aktiviti dan serta penggunaan prasarana. Manakala bagi pengurusan program tak langsung adalah yang tidak melibatkan peserta berhadapan terus secara langsung dengan pihak pengurusan seperti pengurusan kewangan, inventori, pengurusan jurulatih, unit data dan lain-lain. Justeru, dalam kajian ini pengurusan program hanya akan mengambilkira bahagian langsung dalam pengurusan program iaitu prasarana dan pengurusan langsung yang berhadapan dengan peserta sahaja memandangkan bahagian ini yang mampu memberi persepsi kepada peserta mengenai pendidikan luar.

Seterusnya, bagi merujuk kepada konteks pendidikan luar, Robiah (1998) mentakrifkan pendidikan sebagai interaksi antara individu-individu dengan individu lain atau interaksi antara individu dengan kumpulan - kumpulan sosial tertentu. Manakala menurut Glover (2014), Pendidikan dapat didefinisikan kepada dua bahagian iaitu latihan dan persekolahan serta aspek pengetahuan dan kebolehan yang diperolehi melalui latihan. Manakala bagi pendidikan luar pula, Ford, (2005) menyatakan bahawa ia terdiri daripada aktiviti mencabar, aktiviti fizikal, aktiviti mengembara atau aktiviti persekitaran. (Mazuki, 2016) menyatakan bahawa pendidikan luar merupakan pembelajaran pelbagai perkara yang mencakupi pelbagai aspek tentang pengetahuan berkaitan kandungan kursus dan kehidupan seharian,

$$
\begin{aligned}
& \text { “........merupakan proses pembelajaran berasaskan pengalamanyang } \\
& \text { mensasarkan perkembangan dan pertumbuhan domain kognitif, afektif } \\
& \text { dan psikomotor secara seiring tanpa mengabaikan salah satu dari } \\
& \text { komponen tersebut" }
\end{aligned}
$$

(sumber:Mazuki,2016.Pembelajaran Berasaskan Pengalaman)

Manakala menurut Pusat Kokurikulum Sabah (Pusat Kokurikulum Sabah, 2014) Pendidikan luar merupakan salah satu daripada pelbagai kaedah pengajaran dan pembelajaran yang amat menarik dan berkesan jika dilaksanakan secara efektif dengan bijaksana serta pendekatan, pemeringkatan, pengolahan dan pengisian aktiviti secara teori dan praktikal membantu pelajar meneroka pengetahuan 
dan pengalaman baru. Justeru, bagi kajian ini pendidikan luar akan dilihat menerusi persepsi pelajar berdasarkan kepada tiga domain psikososial tersebut iaitu kognitif, afektif dan psikomotor.

\section{Interaksi Sosial}

Interaksi sosial di Pusat merupakan satu perkara asas dalam membentuk perpaduan, kerjasama dalam sesebuah pasukan. Di Pusat kokurikulum, pelajar-pelajar yang hadir ke program-program pilihan Pusat Kokurikulum digalakkan berinteraksi diantara mereka bagi meningkatkan kesefahaman,kejelekitan dan kesepakatan diantara mereka dalam melakukan sesuatu tugasan. Aktiviti-aktiviti di dalam program seperti pecah bendungan, keyakinan dan keselamatan di air, permainan kooperatif, permainan inisiatif, kembara adalah diantara aktiviti yang mempercepatkan proses interaksi sosial diantara peserta ini. Walgito (2003) mengatakan interaksi sosial adalah hubungan individu dengan individu lain yang mana setiap mereka saling mempengaruhi diantara satu dengan yang lain. Manakala santoso (2010) menjelaskan bahawa interaksi sosial mampu memberi kesan peningkatan keatas kemampuan peribadi atau tingkahlaku seseorang untuk untuk berinteraksi dengan individu lain, dengan maksud lain interaksi sosial mampu mematangkan pergaulan individu dengan individu lain. Bagi tujuan interaksi sosial ini, peserta haruslah bijak berkomunikasi, membuat penyesuaian diri didalam kumpulan sosial dan mempunyai tanggungjawab sosial di dalam pasukannya sebagai salah satu aset yang akan menampilkan bakat sebagai individu yang mampu saling mempengaruhi dan mampu memimpin. Justeru, dalam kajian ini interaksi sosial akan melibatkan penilaian peserta keatas komunikasi (interpersonal), penyesuaian diri dan tanggungjawab sosial mereka.

\section{Tujuan Kajian}

Melalui perubahan-perubahan dalam dunia pendidikan masa kini, tuntutan kearah pemaksimuman penggunaan sumber dalam menghasilkan impak besar dengan berpandukan kepada Pelan Pembangunan Pendidikan Malaysia (PPIM 2013-2025) yang dirancang pastinya menjadi tumpuan utama bagi tujuan kajian ini. Pendidikan luar merupakan suatu cara dalam menghubungkait pelbagai bidang pembelajaran yang diletakkan dalam satu bumbung bagi memastikan pelajar menerima terus secara langsung pembelajaran menerusi aktiviti sebenar yang dijalankan. Justeru, penilaian terhadap pengurusan program pendidikan luar dibawah kendalian Pusat Kokurikulum Negeri Sabah itu sendiri harus mantap dari pelbagai aspek sama ada teknikal, teori dan aplikasi. Mengetengahkan keperluan pendidikan luar di serap dan diwujudkan kedalam segenap peringkat sistem pendidikan bermula dengan peringkat prasekolah sehingga ke peringkat universiti juga menjadi perkara pokok bagi tujuan kajian memandangkan pendidikan luar membantu dalam membina kemahiran insaniah murid sekaligus menyokong perancangan Aspirasi Murid di dalam PPIM yang sedang rancak digerakkan pada masa kini.

\section{Objektif Kajian}

i. Mengenal pasti tahap pengurusan program pendidikan luar berdasarkan persepsi pelajar

ii. Mengenalpasti tahap interaksi sosial pelajar dalam program pendidikan luar

iii. Mengenal pasti hubungan antara pengurusan program dengan interaksi sosial pelajar dalam program pendidikan luar

iv. Mengenalpasti pengaruh pengurusan program terhadap interaksi sosial pelajar dalam program pendidikan luar

\section{Batasan Kajian}

Kajian ini hanya melibatkan pelajar yang bernaung dibawah Kementerian pendidikan Malaysia. Pengurusan program yang dilakukan juga adalah dengan berpandukan kepada pekeliling dari semasa ke semasa yang berkuatkuasa yang tertakluk dibawah Kerajaan Malaysia sahaja. Pusat Kokurikulum 
Negeri Sabah mempunyai kapasiti dan kemampuan dalam skala yang besar untuk melaksanakan program-program pendidikan luar. Terdapat 4 buah Pusat kokurikulum di Sabah yang terletak di daerah Kudat, Keningau, Lahad Datu dan Tuaran. Kajian hanya akan berfokus di Sabah iaitu kepada Pusat Kokurikulum Negeri yang berpusat di daerah Tuaran memandangkan 3 buah Pusat Kokurikulum lagi adalah berstatus Pusat Kokurikulum Daerah dan tidak mempunyai kelengkapan yang mencukupi untuk melaksanakan program-program besar yang diperlukan dalam melaksanakan aktiviti pendidikan luar. Selain itu, bagi pengurusan program, tahap pengurusan program hanya mengambilkira aspek pengurusan langsung yang melibatkan pelajar sahaja seperti proses pendaftaran dan juga penggunaan prasarana secara umum. Aspek pengurusan tidak langsung seperti perbelanjaan kewangan, perbincangan jurulatih dan pihak pengurusan tidak dinilai memandangkan ia tidak melibatkan pelajar secara terus atau langsung.

\section{Kaedah Kajian}

Kajian dijalankan dengan menggunakan rekabentuk kajian berbentuk bukan eksperimen yang lebih sesuai bagi sains sosial. Ia mengambil pendekatan kuantitatif sebagai teras utama dalam menjalankan kajian ini. Dapatan penganalisaan akan dijelaskan dalam bentuk statistik deskriptif yang memperihalkan mengenai ciri-ciri reponden dengan menggunakan taburan kekerapan, peratus dan min. Manakala statistik inferensi juga akan digunakan sebagai lanjutan dalam mengenalpasti hubungan dan pengaruh yang wujud diantara kedua pembolehubah ini. Bagi tujuan ini, korelasi pearson dan ujian regresi linear dijalankan untuk menjelaskan keadaan pembolehubah yang terlibat. Manakala dari segi instrumen kajian, pengkaji menggunakan kaedah borang soal selidik bagi mendapatkan maklumat yang tepat dan sahih tanpa perubahan daripada responden sendiri. Instrumen kajian (soal selidik) telah diambil daripada beberapa sumber dan diubahsuai berdasarkan kesesuaian kajian. Antara sumber borang soal selidik yang digunakan bagi soalan pengurusan program adalah Chelladurai dan Saleh (1980), Anuar (2010), Adenan (1999),IPP -Instrumen Penilaian Program Pusat Kokurikulum Negeri Sabah.(Bahagian Pengurusan Sekolah Harian, Kementerian Pendidikan Malaysia). Manakala bagi interaksi sosial, sumber soal selidik yang terlibat adalah berdasarkan sumber seperti Schutte et al (1998), Tapia, M (2001), dan Hamidah (2013). Kesahan dan kebolehpercayaan kajian telah dilakukan dan mendapati instrumen kajian secara keseluruhan melepasi nilai 0.8 bagi nilai alpha cronbach (kebolehpercayaan) dan Kaiser Mayer Olkin (KMO) (analisis faktor). Bagi tujuan persampelan kajian ini, responden yang terlibat adalah daripada kawasan Pantai Barat Selatan sabah iaitu 4 buah sekolah rendah dan sebuah sekolah menengah. Tiga buah sekolah rendah daripada daerah Kota Belud dan sebuah sekolah rendah dari Daerah Tuaran. Manakala bagi sekolah Menengah, ia juga berasal dari Kota Belud. Kajian ini juga telah menggunakan sampel rawak mudah diperingkat akhir pemilihan sampel bagi memastikan responden yang menjawab soalan soal selidik adalah bebas daripada sebarang bias semasa menjawab soalan yang diberikan.

\section{Kerangka Konsep}

Berdasarkan kepada gambarajah 1.0 dibawah, kerangka konseptual yang dibina dibahagikan kepada dua bahagian utama iaitu pembolehubah bersandar dan tidak bersandar.

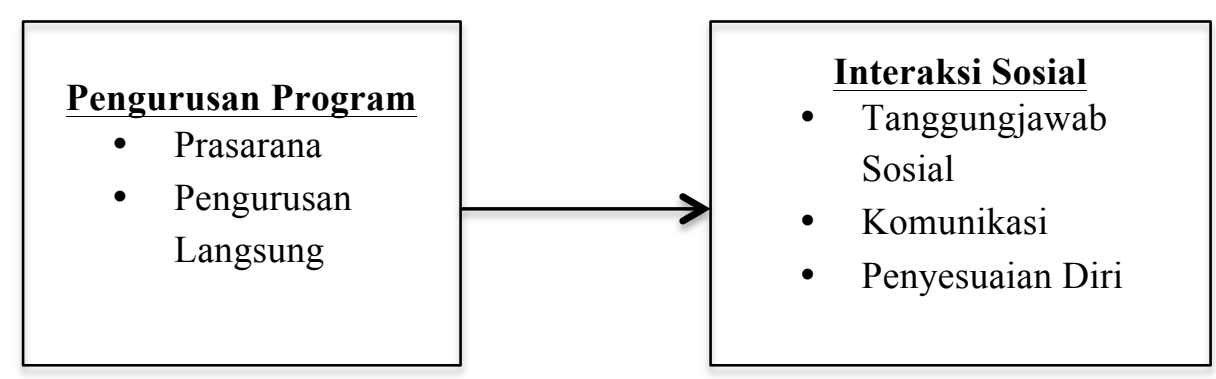

Gambarajah 1: Kerangka kajian 
Setiap pembolehubah mempunyai dimensi masing-masing. Bagi Pembolehubah tidak bersandar iaitu Pengurusan Program, terdapat dua dimensi yang mewakilinya iaitu prasarana dan pengurusan langsung. Manakala bagi pembolehubah bersandar iaitu interaksi sosial, terdapat 3 dimensi yang mewakilinya iaitu komunikasi, tanggungjawab sosial dan penyesuaian diri. Kerangka konsep dibangunkan dengan melihat kepada teori Tyler (1969) yang berkisarkan kepada teori pengurusan program berasaskan pendidikan dan teori Taylor (Jones dan George, 2013) yang menggunakan pendekatan pengurusan saintifik. Manakala bagi interaksi sosial, pendekatan yang digunakan adalah berdasarkan kepada teori pembangunan proksimiti Vygotsky yang mengandungi konsep perancah (scaffolding) iaitu bantuan sokongan berdasarkan kepada tahap-tahap tertentu bagi merangsang individu untuk lebih berusaha (Thomas, 2007; Visscher, 2015; Gauci, 2016).

\section{Dapatan Kajian}

\section{Profil Responden Kajian}

Berdasarkan kepada jadual 1.0 dibawah, responden yang terlibat terdiri dari 44 orang lelaki (38.9\%) dan perempuan seramai 69 orang $(61.1 \%)$ dan menjadikan jumlah keseluruhan sebanyak 113 responden terpilih yang telah berjaya menghantar instrument kajian tanpa sebarang kecacatan dan ketinggalan di dalam pengisian instrument kajian. Manakala bagi taburan kekerapan kaum yang terlibat dalam mengisi instrument kajian. Kajian mendapati responden didominasi oleh dua kaum utama di Sabah iaitu kaum Kadazan/Dusun adalah yang tertinggi dengan kekerapan sebanyak 64 orang (56.6\%) dan kaum Bajau dengan kekerapan sebanyak 37 orang $(32.7 \%)$ diikuti dengan kaum-kaum lain yang menyumbang dengan jumlah responden yang sedikit. Akhir sekali, responden yang terluibat adalah seramai 60 orang $(53.1 \%)$ daripada sekolah rendah, manakala sekolah seramai 53 orang $(46.9 \%)$.

Jadual 1.0: Profil Responden Kajian

\begin{tabular}{lcc}
\hline \multicolumn{1}{c}{ Item } & Kekerapan (Bil.) & Peratusan (\%) \\
\hline Jantina & & \\
$\quad$ Lelaki & 44 & 38.9 \\
Perempuan & 69 & 61.1 \\
Kaum & 64 & 56.6 \\
$\quad$ Kadazan/Dusun & 5 & 4.4 \\
Brunei & 3 & 2.7 \\
Melayu Semenanjung & 1 & 0.9 \\
Murut & 37 & 32.7 \\
Bajau & 1 & 0.9 \\
India & 1 & 0.9 \\
Lundayeh/Linbawang & 1 & 0.9 \\
Lain-lain Bumiputra Sabah & & \\
Kategori & 60 & 53.1 \\
$\quad$ Sekolah Rendah & 53 & 46.9 \\
$\quad$ Sekolah Menengah & & \\
\hline
\end{tabular}

Bagi mengenalpasti tahap pengurusan program dan interaksi sosial berdasarkan persepsi pelajar di dalam program pendidikan luar ini, tafsiran nilai min dilihat berpandukan kepada Wan Rezawana, et.al, (2018) dengan berpandukan tafsiran min yang diubahsuai daripada Julie Pallant (2007) yang mengenakan tiga peringkat tafsiran iaitu 1.00 hingga 2.33 berada pada tahap rendah, 2.34 hingga 3.67 berada pada tahap sederhana dan 3.68 hingga 5.00 berada pada tahap tinggi. Dengan merujuk kepada jadual 2.0, dapat dilihat secara keseluruhan nilai min yang diperolehi oleh pengurusan program adalah berada dalam lingkungan $(3.68<4.33<5.00)$ dengan kedua-dua dimensi di dalam pengurusan program menyumbang kepada nilai min yang tinggi iaitu 4.47 bagi prasarana dan 4.24 bagi pengurusan langsung. 
Jadual 2 : Tahap Pengurusan Program

\begin{tabular}{lccc}
\hline Pembolehubah & N & Min & Sisihan Piawai \\
\hline (Prasarana) & 113 & 4.47 & 0.46 \\
(Pengurusan Langsung) & 113 & 4.24 & 0.45 \\
Pengurusan Program & 113 & 4.33 & 0.41 \\
\hline
\end{tabular}

Seterusnya bagi interaksi sosial, secara keseluruhan nilai min yang ditunjukkan adalah sedikit rendah berbanding nilai min keseluruhan pengurusan program, namun ia masih lagi mencapai lingkungan nilai min yang termasuk dalam kategori tinggi $(3.68<4.23<5.00)$. Keadaan ini dapat dilihat menerusi tiga dimensi penyumbang kearah nilai tersebut yang mana nilai bagi penyesuaian diri adalah sedikit rendah berbanding lain iaitu 4.14 berbanding komunikasi 4.27 dan tanggungjawab sosial dengan nilai min 4.29 .

Jadual 3 : Tahap Interaksi sosial

\begin{tabular}{lccc}
\hline Pembolehubah & N & Min & Sisihan Piawai \\
\hline (Tanggungjawab Sosial) & 113 & 4.29 & 0.48 \\
(Komunikasi) & 113 & 4.27 & 0.52 \\
(Penyesuaian Diri) & 113 & 4.14 & 0.58 \\
Interaksi Sosial & 113 & 4.23 & 0.48 \\
& & & \\
\hline
\end{tabular}

Dapatan kajian juga menunjukkan bahawa terdapat hubungan diantara pengurusan program dan interaksi social. Bagi menjelaskan kekuatan hubungan, penyelidik menggunakan pandangan pallant (2007) yang merujuk kepada cohen (1988) yang menyatakan bahawa kekuatan nilai 0.1 hingga 0.29 adalah kecil, 0.30 hingga 0.49 adalah sederhanan dan 0.50 sehingga 1.00 adalah besar. Dalam kes ini hubungan diantara pengirisan program dan interaksi social adalah bersifat sederhana dan positif memandangkan nilai 0.469 berada dalam lingkungan 0.30 hingga 0.49 seperti yang dapat dilihat dalam jadual 4.0 dibawah.

Jadual 4 : Korelasi pembolehubah

\begin{tabular}{llrr}
\hline & & Interaksi Sosial & $\begin{array}{c}\text { Pengurusan } \\
\text { Program }\end{array}$ \\
\hline Pearson Correlation & Interaksi Sosial & 1.000 & $.469^{* *}$ \\
Sig. (2-Tailed) & Pengurusan Program & $.469^{* *}$ & 1.000 \\
\multirow{2}{*}{$\mathrm{N}$} & Interaksi Sosial &. & .000 \\
& Pengurusan Program & .000 &. \\
& Interaksi Sosial & 113 & 113 \\
& Pengurusan Program & 113 & 113 \\
\hline \multicolumn{2}{c}{$*$. Correlation is significant at the 0.01 level (2-tailed). }
\end{tabular}

Manakala bagi hasil analisis regresi yang dijalankan, dapat dilihat berdasarkan jadual 5.0 dibawah bahawa nilai $\mathrm{R}$ square adalah 0.220 yang menunjukkan bahawa sebanyak $22 \%$ varians dalam pembolehubah pengurusan program mampu menjelaskan mengenai pembolehubah bersandar iaitu interaksi sosial $\left(\mathrm{F}_{1,111}=31.360, \mathrm{k}<0.05\right)$. Berdasarkan kepada pekali regresi juga dapat difahami bahawa (Beta $=0.469),(\mathrm{t}=5.600, \mathrm{k}<0.05)$ hubungan diantara pengurusan program dan interaksi sosial adalah suatu hubungan yang linear dan signifikan. Keadaan ini menunjukkan bahawa pengurusan program sebenarnya mempunyai peranan dalam meningkatkan atau membataskan interaksi social diantara pelajar dalam sesebuah program yang dijalankan di dalam program pendidikan luar.

Jadual 5: Jadual nilai regresi

\begin{tabular}{llll}
\hline Pembolehubah & $\boldsymbol{t}$ & $\boldsymbol{P}$ \\
\hline
\end{tabular}




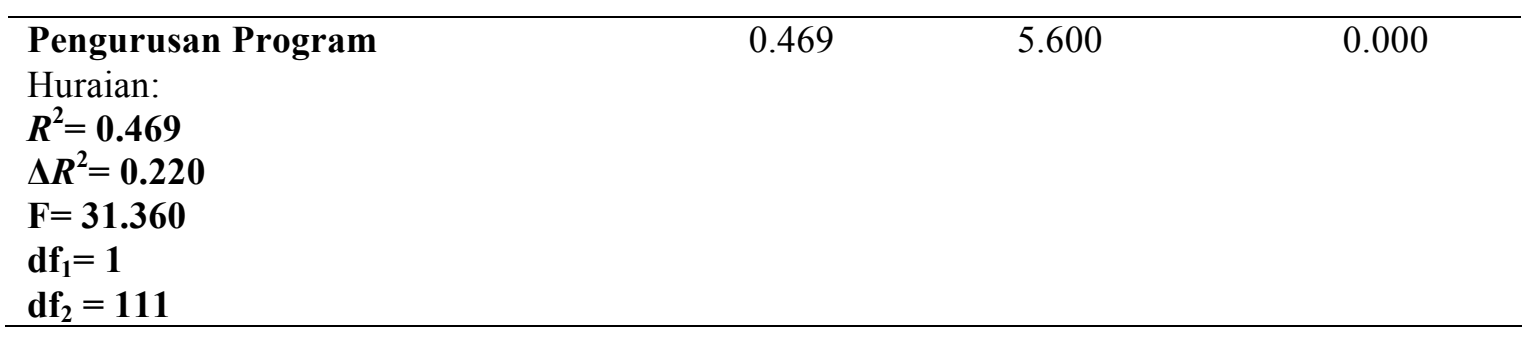

\section{Perbincangan Dan Implikasi}

Kajian ini memberikan hasil jawapan bahawa sebenarnya pengurusan program mempunyai hubungkait tentang bagaimana interaksi sosial berlaku dalam program pendidikan luar. Dalam konteks pengurusan pusat kokurikulum, pengurusan program memainkan peranan penting dalam memastikan setiap aktiviti yang dirancang atau program yang dijalankan dilaksanakan mengikut garis panduan yang ditetapkan oleh Kementerian Pendidikan Malaysia (Laporan Tahunan Pusat Kokurikulum Sabah, 2016). Justeru, pengurusan program yang lemah dan tersasar daripada landasan atau garis panduan yang ditetapkan oleh Kementerian Pendidikan Malaysia akan menghasilkan sesuatu produk atau kesan yang berimpak negatif kepada modal insan yang bakal dibina memandangkan interaksi sosial sebenarnya mempunyai nilai dan elemen kemahiran insaniah yang sepatutnya dipupuk dengan tepat dan betul agar modal insan yang terhasil mengikut acuan yang dirancang berdasarkan kepada Pelan Induk Pembangunan Pendidikan Malaysia (PPPIM)(Kementerian Pendidikan Malaysia, 2018).

Impak atau implikasi yang terhasil daripada kajian ini dapat dihubungkaitkan kepada tiga perkara utama iaitu dari segi penggunaan dan pelaksanaan teori, usaha kesinambungan penyelidikan. Berdasarkan kepada penggunaan teori yang telah dinyatakan sebelum ini, dapatan kajian telah menunjukkan bahawa kajian ini sebenarnya menunjukkan kecenderungan kearah sokongan terhadap teori yang dipelopori oleh Vygotsky dalam menanamkan asas konsep perancah (scaffolding) bagi memberi bantuan atau sokongan atau rangsangan terhadap individu dengan merujuk kepada tahaptahap tertentu bagi menjadikan individu itu lebih berusaha (Thomas, 2007; Visscher, 2015; Gauci, 2016). Dalam hal ini, pengurusan program pendidikan luar yang dibentuk oleh Pengurusan Pusat Kokurikulum Sabah sebenarnya telah memainkan peranan dalam memberikan platform yang terbaik bagi meningkatkan interaksi sosial diantara pelajar dalam keadaan terkawal mengikut acuan yang disarankan oleh Kementerian Pendidikan Malaysia. Dengan maksud lain, jika pihak pengurusan program Pusat Kokurikulum Sabah gagal memberikan perancangan dan platform yang baik, maka interaksi sosial di dalam pengurusan program berkemungkinan besar akan gagal dan hal ini akan seterusnya mendorong kepada kegagalan proses integrasi perpaduan kaum yang diharapkan di dalam pembangunan modal insan Malaysia.

Manakala dari segi pengurusan program itu sendiri, sokongan terhadap teori saintifik yang dipelopori Frederick Taylor telah membuahkan hasil dengan menjadikan pengurusan program lebih efisyen dan mampu menjadikan pengurusan program itu sendiri mempengaruhi proses interaksi sosial memandangkan melalui pengurusan program (pengurusan langsung) pelajar atau peserta boleh diatur sama ada berada dalam kelompok sendiri atau disusun dengan proses integrasi selain fungsi pengurusan langsung itu sendiri yang berusaha mendekatkan peserta diantara satu sama lain dengan proses sistematik yang telah dirancang (Muhammad Faizal, Norfariza, Saedah, Faisol, Zulkifli, Shahril, 2012 ; Jones dan George, 2013). Seterusnya dari segi impak terhadap penyelidikan pula, kajian ini telah membuka ruang yang lebih luas untu pengurusan program dan interaksi sosial sebenarnya untuk dimajukan ke tahap yang lebih jauh lagi melalui penemuan tahap signifikan yang terhasil diantara pengurusan program dan interaksi sosial. Ruang lingkup pengurusan program yang telah membuktikan bahawa ia berperanan dalam mempengaruhi tahap inetraksi sosial seharusnya dimanfaatkan oleh penyelidik-penyelidik seterusnya yang berminat mengkaji pada bahagian ini terutama bagaiman fokus pengurusan program itu sendiri dari segi sudut-sudut tertentu mengawal dan meningkatkan hubungan diantara peserta program dengan efektif tanpa melalui sebarang konflik diantara jantina, kaum dan agama. Terdapat pengkaji sebelum ini mencadangkan kajian yang melibatkan kognitif, afektif dan psikomotor dalam latihan (Azman Ismail dan Nurul Inani Ibrahim, 2010), Oleh itu kajian ini juga 
sebenarnya secara tidak langsung dapat digunakan oleh pengkaji yang akan datang melihat penekanan kognitif, afektif dan psikomotor dalam interaksi sosial ataupun menggabungkannya dengan faktor latihan memandangkan pengurusan program menentukan hala tuju ataupun objektif yang ingin dicapai oleh murid dalam sesuatu program tersebut. Justeru, hala tuju tersebut akan menentukan bagaimana pelajar akan berfikir (kognitif), merasa (afektif) dan bertindak (psikomotor) seperti yang diharapkan oleh sesebuah program.

\section{Rumusan}

Sebagai penutup atau rumusan, kajian menyimpulkan bahawa fungsi campur tangan pengurusan program dalam menjalankan sesebuah program atau aktiviti pendidikan luar tersebut mempunyai kesan atau pengaruh terhadap interaksi sosial pelajar atau peserta yang terlibat di dalam program tersebut. Sungguhpun pengaruh yang dapat disimpulkan adalah bersifat sederhana, namun dapat difahami bahawa semakin tersusun dan sistematik sesebuah pengurusan program dalam menggalakkan interaksi sosial yang terkawal, maka semakin tinggi dan baiklah corak interaksi sosial yang terhasil. Keadaan ini sebenarnya mempunyai hubungkait dengan objektif pengurusan program itu sendiri, justeru objektif pengurusan program yang ekspkisit juga harus disertai dengan objektif implisit yang membantu pelajar meningkatkan kemahiran insaniah mereka.

\section{Rujukan}

Anuar Bin Din, \& Salleh Abd Rashid. (2006). Gaya Kepimpinan Jurulatih Dalam Program Latihan, (2003), 1-13.

Anuar Din, Salleh Abd Rashid, \& Mohd Isha Awang. (2015). Aspek Pengurusan Program Latihan Dan Kesannya Terhadap Kepuasan Atlet Sekolah Sukan Management Training Programme And Its Effect On The Sports School Athletes' Satisfaction. Ijms, 22(221), 73-95.

Azman Ismail, dan Nurul Inani Ibrahim. (2010). Motivasi latihan sebagai pembolehubah penghubung antara program latihan dan keberkesanan latihan. Jurnal Kemanusiaan, 6, 84-94.

Ford, P.M. (2005). Principles And Practise Of Outdoor Environmental Education. New York: John Wiley And Sons.

Glover Jeffrey T. (2014). Adventure Movement Project: Building A Sustainable Adventure Movement. Prescott College.Arizona.Usa.

Gray, T., \& Martin, P. (2012). The Role And Place Of Outdoor Education In The Australian National Curriculum. Australian Journal Of Outdoor Education, 16(1), 43-54.

Irwin, D., \& Straker, J. (2015). Tenuous Affair: Environmental And Outdoor Education In Aotearoa New Zealand. Australian Journal Of Environmental Education, 30(2), 151-166. Https://Doi.Org/10.1017/Aee.2015.9

Jones, G. R., \& George, J. M. (2015). Contemporary Management.Ninth Edition.Mcgraw Hill Education.

Kementerian Pendidikan Malaysia. (2012). Laporan Awal-Ringkasan Eksekutif Pelan Pembangunan Pendidikan Malaysia 2013-2025. Pelan Pembangunan Pendidikan Malaysia 2013-2025. Https://Doi.Org/10.1017/CBO9781107415324.004

Laporan Tahunan Pusat Kokurikulum Negeri Sabah 2011.(2012). Pusat Kokurikulum Negeri Sabah, Jabatan Pendidikan Negeri Sabah

Laporan Tahunan Pusat Kokurikulum Negeri Sabah 2015.(2016). Pusat Kokurikulum Negeri Sabah, Jabatan Pendidikan Negeri Sabah

Laporan Tahunan Pusat Kokurikulum Negeri Sabah 2016.(2017). Pusat Kokurikulum Negeri Sabah, Jabatan Pendidikan Negeri Sabah

Mazuki Bin Mohd Yasim. (2016). Effects Of Outdoor Education On Group Cohesion Among Second Year Undergraduate Teacher Trainees From Selected Teacher. Universiti Putra Malaysia

Mohd Salleh Aman. (2005). Asas Pengurusan Sukan. Kuala Lumpur: Penerbit Universiti Malaya.

Omar Firdaus B. Mohd Said. (2016). Kesan Program Perkhemahan Pendidikan Luar Terhadap Sikap Alam Sekitar Dalam Kalangan Pelajar Sekolah Menengah Daerah Sabak Bernam. Fakulti Sains Sukan Dan Kejurulatihan Universiti Pendidikan Sultan Idris (UPSI). 
Robiah Sidin .(1998). Pemikiran Dalam Pendidikan.Halaman 3.Shah Alam: Penerbit Fajar Bakti Sdn. Bhd

Rorlinda Yusof, Noriah Mohd Ishak, Siti Aishah Hassan, \& Afifah Mohd Radzi. (2016). Kajian Jatidiri Dan Tekanan Isu Sosio-Emosi Dalam Kalangan Pelajar Pintar Dan Berbakat (a Study of Identity and Socio- Emotional Stress Among Intelligent and Talented Students). Jurnal Psikologi Malaysia, 30(2), 42-60.

Santoso, S. (2010). Teori-Teori Psikologi Sosial. Yogyakarta: Reflika Aditama

Spiers, A. J. W., \& A. (2012). Achieving A Better Understanding Of Outdoor Recreation Conflict And Its Management In Canada' S National Parks.

Taff, Md Amin Md, Aziz, Azlizam Abdul, \& Zakaria, J. (2011). Kerelevanan Pendidikan Luar Dalam Sistem Pendidikan Tinggi Di Malaysia. Ajtlhe, 3(1), 11-27. Https://Doi.Org/10.1017/Cbo9781107415324.004

Thomas, G. (2007). A Study Of The Theories And Practices Of Facilitator Educators, 1-216. La Trobe University. Bundoora, Victoria 3086 Australia. retrieved From Https://Espaceweb1.Library.Uq.Edu.Au/Eserv/Uq:240921/Thomas_Doctoral_Thesis.Pdf

Tyler, Ralph W. (1969). Basic Principles Of Curriculum And Instruction. Chicago: The University Of Chicago Press.

Walgito, B. (2003). Psikologi Sosial Suatu Pengantar. Yogyakarta: Andi Offset. 